\title{
Vegetation Database of Mountain Wetlands of Iran
}

\author{
Alireza Naqinezhad
}

\begin{abstract}
There is a wide range of wetland vegetation in the steppic mountain areas of Iran particularly on the two largest ranges of Iran, the Zagros in the West and the Alborz in the North. The wetland habitats are sharply embedded within vegetation of the IranoTuranian steppes that are more characteristic of this region and are of interest both in themselves and for wider comparison with EuroSiberian wetlands. There is little knowledge regarding these wetlands in Iran. We planned to collect all relevé data on these wetlands. At first, data on the wetland vegetation of Alborz were collected. Up to now, more than 1,000 relevés have been collected. This report describes the available content in the Vegetation Database of Mountain Wetlands of Iran (GIVD ID AS-IR-002).
\end{abstract}

Keywords: Alborz; mountain wetland; steppe.

\section{Vegetation Database of Mountain Wetlands of Iran}

Scope: There is a wide range of wetland vegetation on the dry Mountains of Iran. The wetland habitats are sharply embedded within vegetation of the Irano-Turanian steppes that are more characteristic of this region and are of interest both in themselves and for wider comparison with Euro-

Siberian wetlands.

Status: emerging

Period: $2007-2012$

Database manager(s): Alireza Naqinezhad (a.naqinezhad@umz.ac.ir)

Owner: A Naqinezhad (private)

Web address: [NA]

Availability: after blocking period

Database format(s): Excel

Publication: [NA]

Plot type(s): normal plots

Non-overlapping plots: 1,000

Total plot observations: 1,000

Countries: IR: $100.0 \%$

Forest: [NA] — Non-forest: [NA]

Guilds: all vascular plants: $100 \%$; bryophytes (terricolous or aquatic): $5 \%$

Environmental data: [NA]

Performance measure(s): [NA]

Geographic localisation: [NA]

Sampling periods: [NA]

Information as of 2012-07-12; further details and future updates available from http://www.givd.info/ID/AS-IR-002

Alireza Naqinezhad (a.naqinezhad@umz.ac.ir)

Department of Biology, Faculty of Basic Sciences, University of Mazandaran, Babolsar, IRAN. 